\title{
Proteomic Analysis of Cold Stress Responses in Banana Leaves
}

\author{
Ren-jun Feng ${ }^{1}$, Li-li Zhang, Jing-yi Wang, Jin-mei Luo, and Ming Peng ${ }^{2}$ \\ Key Laboratory of Biology and Genetic Resources of Tropical Crops, Ministry of Agriculture, \\ Institute of Tropical Bioscience and Biotechnology, Chinese Academy of Tropical Agricultural \\ Sciences (CATAS), Haikou 571101, P.R. China
}

Jun-feng $\mathbf{Q i}^{\mathbf{1}}$ and Yin-don Zhang ${ }^{2}$

College of Agronomy, Hainan University, Haikou 570228, P.R. China

Li-fang Lu

Hainan Institute of Science \& Technology, Haikou 571126, P.R. China

\begin{abstract}
Additional INDEX words. two-dimensional gel electrophoresis, mass spectrometry, differential proteins, reactive oxygen species, antioxidation, anti-pathogen, energy supply

Abstract. Cold stress is one of the most important environmental factors affecting crop growth and agricultural production. Induced changes of gene expression and metabolism are critical for plants responding and acclimating to cold stress. Banana (Musa sp.) is one of the most important food crops in the tropical and subtropical countries of the world. Banana, which originated from tropical regions, is sensitive to cold, which can result in serious losses in commercial banana production. To investigate the response of the banana to cold stress conditions, changes in protein expression were analyzed using a comparative proteomics approach. 'Brazil' banana (Musa acuminata AAA group) is a common banana cultivar in southern China. 'Brazil' banana plantlets were exposed to $5^{\circ} \mathrm{C}$ for 24 hours and then total crude protein was extracted from treatment and control leaves by phenol extraction, separated with twodimensional gel electrophoresis, and subsequently identified by mass spectrometry (MS). Out of the more than 400 protein spots reproducibly detected, only 41 protein spots exhibited a change in intensity by at least 2 -fold, with 26 proteins increasing and 15 proteins decreasing expression. Of these, 28 differentially expressed proteins were identified by MS. The identified proteins, including well-known and novel cold-responsive proteins, are involved in several cellular processes, including antioxidation and antipathogen, photosynthesis, chaperones, protein synthesis, signal transduction, energy metabolism, and other cellular functions. Proteins related to antioxidation, pathogen resistance, molecular chaperones, and energy metabolism were up-regulated, and proteins related to ethylene synthesis, protein synthesis, and epigenetic modification were down-regulated in response to cold temperature treatment. The banana plantlets incubated at cold temperatures demonstrated major changes in increased reactive oxygen species (ROS) scavenging, defense against diseases, and energy supply. Increased antioxidation capability in banana was also discovered in plantain, which has greater cold tolerance than banana in response to cold stress conditions. Therefore, we hypothesized that an increased antioxidation ability could be a common characteristic of banana and plantain in response to cold stress conditions. These findings may provide a better understanding of the physiological processes of banana in response to cold stress conditions.
\end{abstract}

Cold stress is one of the major environmental factors that often affects crop growth, productivity, quality, and postharvest life (Sanghera et al., 2011). Cold stress can be classified as chilling $\left(0\right.$ to $\left.15^{\circ} \mathrm{C}\right)$ or freezing $\left(<0{ }^{\circ} \mathrm{C}\right)$ stress. To cope with such conditions, plants require specialized mechanisms to survive. Plants originating from temperate regions that are exposed to low, nonfreezing temperatures exhibit an increase in the extent to which they can tolerate freezing, which is a phenomenon known as "cold acclimation" (Thomashow, 1999). Significant progress has been made in understanding the molecular mechanisms that lead to cold acclimation in plants such as arabidopsis [Arabidopsis thaliana (Miura and Furumoto,

Received for publication 27 Oct. 2014. Accepted for publication 26 Feb. 2015. This research was supported by grants from the National Nature Science Foundation of China (31201603), National High Technology Research and Development Program of China (863 Program; No. 2012AA101204-2), The Major Science and Technology program of Hainan (ZDZX2013023-1), and the Hainan Natural Science Foundation (312051).

${ }^{1}$ These authors contributed equally to this work.

${ }^{2}$ Corresponding author. E-mail: mmpeng_2000@yahoo.com, zhangyindong@itbb. org.cn.
2013)], winter wheat (Triticum aestivum), and rye (Secale cereale) (Chinnusamy et al., 2007). To adapt to cold stress, gene expression is reprogrammed and metabolism is modified through alterations in transcriptional and posttranscriptional regulation as well as translational and posttranslational regulation of cold stress signaling during cold acclimation (Barrero-Gil and Salinas, 2013; Miura and Furumoto, 2013). However, plants originating from tropical and subtropical origins are sensitive to chilling stress and lack this described cold acclimation mechanism. Proteomics is a powerful molecular tool for investigating the complete proteome in the organelle, cell, organ, or tissue at a given time point or under given physiological conditions and for comparing how the proteome is affected by different physiological conditions (Sobhanian et al., 2010). In addition, the combination of proteomics with measurements of changes in complementing transcriptome levels can identify translational and posttranslational regulations (Ghosh and $\mathrm{Xu}, 2014$ ). A comparative proteomic approach has recently emerged as a powerful and promising tool for identifying genes and pathways that are crucial for stress responsiveness and tolerance of plants (Abdalla and Rafudeen, 2012; Gao et al., 2011; Zhang et al., 2010). 
Moreover, several proteomic studies have been successfully performed in banana (Carpentier et al., 2007; Esteve et al., 2013; Samyn et al., 2007; Toledo et al., 2012; Vanhove et al., 2012; Zhang et al., 2012).

Musa species, including bananas and plantains, are the fourth most important crop in developing countries (Lescot et al., 2008) and are giant perennial herbs from the monocot order Zingiberales, which originated in Southeast Asia and the western Pacific (Davey et al., 2013). Cultivated bananas and plantains are mainly triploids that derive from intraspecific hybridizations within Musa acuminata (A genome) and interspecific hybridizations with Musa balbisiana (B genome) (Davey et al., 2013). The current production mainly relies on somaclones derived from a single triploid genotype, 'Cavendish' (D'Hont et al., 2012). Banana, which originated from tropical regions, is cultivated in tropical and subtropical regions throughout the world (Heslop-Harrison and Schwarzacher, 2007) and is sensitive to cold. Importantly, cold stress can result in serious loss in commercial banana production (Feng et al., 2010).

Our understanding to date of cold stress mechanisms in banana is limited. Therefore, in this study we used a comparative proteomic approach in an attempt to examine the effects of the earliest stages of cold stress on banana at the protein level. We show that 28 proteins altered in response to cold stress in banana, including well-known and novel cold-responsive proteins, are involved in several cellular processes, including antioxidation and antipathogen, photosynthesis, chaperones, protein synthesis, signal transduction, energy metabolism, and other cellular functions. The banana plantlets grown at cold temperatures demonstrated major changes including increased ROS scavenging, defense against diseases, and energy supply. Moreover, identification of cold stress response-related proteins could be useful biomarkers for facilitating conventional breeding approaches for cold-tolerant banana cultivars.

\section{Materials and Methods}

Plant materials AND treatment. 'Brazil' banana plantlets were cultivated in $15-\mathrm{cm}$ plastic pots filled with a mixture of loam and coconut husk $(60: 40, \mathrm{v} / \mathrm{v})$ under greenhouse conditions at the Institute of Tropical Bioscience and Biotechnology, Haikou, China. Greenhouse conditions were $12 \mathrm{~h}$ of light $\left(300 \mu \mathrm{mol} \cdot \mathrm{m}^{-2} \cdot \mathrm{s}^{-1}\right.$ fluorescent lamps) at $28{ }^{\circ} \mathrm{C}$ and $12 \mathrm{~h}$ of darkness at $20^{\circ} \mathrm{C}$. The relative humidity was maintained at $80 \%$. The plantlets were watered twice per week with tap water and once per week with a plant nutrient solution $\left[0.7 \mathrm{~g} \cdot \mathrm{L}^{-1} \mathrm{KNO}_{3}, 0.7 \mathrm{~g} \cdot \mathrm{L}^{-1} \mathrm{Ca}\left(\mathrm{NO}_{3}\right)_{2}\right.$, $0.8 \mathrm{~g} \cdot \mathrm{L}^{-1} \mathrm{Ca}\left(\mathrm{H}_{2} \mathrm{PO}_{4}\right)_{2} \cdot \mathrm{H}_{2} \mathrm{O}, 0.28 \mathrm{~g} \cdot \mathrm{L}^{-1} \mathrm{MgSO}_{4}, 0.12 \mathrm{~g} \cdot \mathrm{L}^{-1} \mathrm{Fe}_{2}$ $\left(\mathrm{SO}_{4}\right)_{3}, 0.6 \mathrm{mg} \cdot \mathrm{L}^{-1}\left(\mathrm{NH}_{4}\right)_{6} \mathrm{MO}_{7} \mathrm{O}_{24} \cdot 4 \mathrm{H}_{2} \mathrm{O}, 0.6 \mathrm{mg} \cdot \mathrm{L}^{-1} \mathrm{H}_{3} \mathrm{BO}_{3}$, $0.6 \mathrm{mg} \cdot \mathrm{L}^{-1} \mathrm{MnSO}_{4}, 0.6 \mathrm{mg} \cdot \mathrm{L}^{-1} \mathrm{ZnSO}_{4}$, and $\left.0.6 \mathrm{mg} \cdot \mathrm{L}^{-1} \mathrm{CuSO}_{4}\right]$. For the cold treatments, plantlets with four well-developed leaves were placed in climate cabinets $(12 \mathrm{~h}$ light $/ 12 \mathrm{~h}$ dark photoperiod at $100 \mu \mathrm{mol} \cdot \mathrm{m}^{-2} \cdot \mathrm{s}^{-1}$ fluorescent lamp) and left at $5{ }^{\circ} \mathrm{C}$ and $70 \%$ relative humidity for $24 \mathrm{~h}$. Independent experiments were carried out three times, and five plantlets were used for each experiment. The mature flag-leaves from cold-treated plantlets and the control were cut by scalpel at $0800 \mathrm{HR}$, and harvested leaves were dipped in liquid nitrogen, and stored at $-80{ }^{\circ} \mathrm{C}$ until needed.

Protein extraction. Proteins from the leaves were extracted according to the phenol procedure previously described (Zhang et al., 2012). The resulting protein pellet was resuspended in an appropriate quantity of lysis buffer $\left(15 \mathrm{~L} \cdot \mathrm{kg}^{-1}\right)$ containing
$9.0 \mathrm{~mol} \cdot \mathrm{L}^{-1}$ urea, $65 \mathrm{mmol} \cdot \mathrm{L}^{-1}$ dithiothreitol (DTT), $40 \mathrm{mmol} \cdot \mathrm{L}^{-1}$ Tris, and 4\% (w/v) 3-[(3-cholamidopropyl)dimethylammonio]1-propanesulfonate (CHAPS) supplemented with $0.8 \%$ immobilized $\mathrm{pH}$ gradients (IPG)-buffer and incubated at room temperature for $1.5 \mathrm{~h}$. After centrifugation at $16,000 g_{\mathrm{n}}$ for $20 \mathrm{~min}$ at $4{ }^{\circ} \mathrm{C}$, the supernatant was stored at $-80^{\circ} \mathrm{C}$. The protein concentration was determined using the Bradford assay (Bradford, 1976). Protein concentration was calculated according to a standard protein curve using bovine serum albumin as a standard. The absorbance was measured using a spectrophotometer (UV2250; Shimadzu Corporation, Kyoto, Japan).

TWo-DIMENSIONAL GEL ELECTROPHORESIS (2-DE). The 2-DE was carried out as previously described (Zhang et al., 2012). Protein concentration was normalized to $1 \mathrm{~g} \cdot \mathrm{L}^{-1}$ in rehydration buffer $\left[8 \mathrm{~mol} \cdot \mathrm{L}^{-1}\right.$ urea, $4 \%(\mathrm{w} / \mathrm{v})$ CHAPS, $10 \%(\mathrm{v} / \mathrm{v})$ glycerol, $0.002 \%$ (v/v) bromophenol blue, $0.5 \%$ (v/v) IPG-buffer, $1 \%(\mathrm{w} / \mathrm{v})$ DTT] and $400 \mu \mathrm{g}$ protein was loaded per gel. Gel strips $(17 \mathrm{~cm}, \mathrm{pH}$ 4-7; Bio-Rad, Hercules, CA) were hydrated for $14 \mathrm{~h}$. Isoelectric focusing (IEF) was performed using the IEF system (Bio-Rad) at $17^{\circ} \mathrm{C}$ with a current limit of $50 \mathrm{~mA} /$ strip: $0.5 \mathrm{~h}$ at $250 \mathrm{~V}, 1 \mathrm{~h}$ at $1000 \mathrm{~V}, 5 \mathrm{~h}$ at $10,000 \mathrm{~V}$, and $60,000 \mathrm{~V}$ h at $10,000 \mathrm{~V}$. Before separation along the second dimension, individual strips were equilibrated for $15 \mathrm{~min}$ in $5 \mathrm{~mL}$ equilibration solution [ $6 \mathrm{~mol} \cdot \mathrm{L}^{-1}$ urea, $20 \%(\mathrm{v} / \mathrm{v})$ glycerol, $2 \%(\mathrm{w} / \mathrm{v})$ sodium dodecyl sulfate (SDS), $0.002 \%(\mathrm{w} / \mathrm{v})$ bromophenol blue, $1.5 \mathrm{~mol} \cdot \mathrm{L}^{-1}$ Tris $\left.\mathrm{pH} 8.8\right]$ containing $2 \%(\mathrm{w} / \mathrm{v})$ DTT and subsequently for $15 \mathrm{~min}$ in $5 \mathrm{~mL}$ equilibration buffer containing $2.5 \%(\mathrm{w} / \mathrm{v})$ iodoacetamide. Separation in the second dimension was performed on a vertical electrophoresis system (Bio-Rad) with $1 \mathrm{~mm}$ SDS polyacrylamide gels (12\%). Electrophoresis was performed for $30 \mathrm{~min}$ at $120 \mathrm{~V}$, followed by $200 \mathrm{~V}$ until the bromophenol blue line ran off. The protein spots were stained with colloidal Coomassie brilliant blue G-250 (cCBB). At least three replicates were performed for each sample.

MS ANALYSIS AND DATABASE SEARCH. 2-DE gels images were captured with a scanner (Powerlook-2100XL; UMAX Technologies, Dallas, TX) and scanned gel images (400 dpi) were imported into Image Master 2D Platinum (Amersham Biosciences, Geneva, Switzerland). The parameters were set as follows: Smooth 6, Mini Area 1, Saliency 8.ooooo. To verify the autodetected result, all spots were manually edited. Three well-separated gels of each sample were named as replicate groups. Statistical and quantitative analyses were used to compare the control group and the treated group. A paired $t$ test and significance level of $95 \%$ were used for the analysis. In the quantitative analysis, the upper limit and the lower limit were set to 2.0 and 0.5 , respectively. The spots were compared among three biological replicates. Only spots displaying reproducible change patterns were considered to be differentially expressed proteins and chosen for further analysis.

Each piece of excised gel was washed twice with $50 \mu \mathrm{L}$ double-distilled water for $10 \mathrm{~min}$ and destained with $50 \mu \mathrm{L}$ of $\mathrm{NH}_{4} \mathrm{HCO}_{3}-\mathrm{CH}_{3} \mathrm{CN}\left(1: 1,50 \mathrm{mmol} \cdot \mathrm{L}^{-1}\right)$ for $20 \mathrm{~min}$ at $37{ }^{\circ} \mathrm{C}$. This step was repeated until the gel was completely destained. Subsequently, $50 \mu \mathrm{L}$ of dehydration buffer containing $\mathrm{CH}_{3} \mathrm{CN}$ was added and the pellet was vacuum filtered for $10 \mathrm{~min}$. The protein in the gel was reduced with $20 \mu \mathrm{L}$ of a solution containing $10 \mathrm{mmol} \cdot \mathrm{L}^{-1}$ DTT and $100 \mathrm{mmol} \cdot \mathrm{L}^{-1} \mathrm{NH}_{4} \mathrm{HCO}_{3}$ for $1 \mathrm{~h}$ at $56^{\circ} \mathrm{C}$. After cooling to room temperature, $55 \mathrm{mmol} \cdot \mathrm{L}^{-1}$ iodoacetamide in $25 \mathrm{mmol} \cdot \mathrm{L}^{-1} \mathrm{NH}_{4} \mathrm{HCO}_{3}(20 \mu \mathrm{L})$ was added quickly and samples were placed in a darkroom for $45 \mathrm{~min}$. The peptides were subsequently extracted using $25 \mathrm{mmol} \cdot \mathrm{L}^{-1}$ $\mathrm{NH}_{4} \mathrm{HCO}_{3}$ for $10 \mathrm{~min}$ (twice), $25 \mathrm{mmol} \cdot \mathrm{L}^{-1} \mathrm{NH}_{4} \mathrm{HCO}_{3}+50 \%$ 
$\mathrm{CH}_{3} \mathrm{CN}$ for $10 \mathrm{~min}$ (twice), and $\mathrm{CH}_{3} \mathrm{CN}$ for $10 \mathrm{~min}$. They were then vacuum dried. The gel piece with the reduced protein was minced, lyophilized, and subsequently rehydrated in 25 $\mathrm{mmol} \cdot \mathrm{L}^{-1} \mathrm{NH}_{4} \mathrm{HCO}_{3}$ with $0.1 \mathrm{~g} \cdot \mathrm{L}^{-1}$ trypsin at $37{ }^{\circ} \mathrm{C}$ overnight. After digestion, the minced gel was washed with $0.1 \%$ trifluoroaceticacid and centrifuged. The resulting peptide mixtures from each protein were analyzed by matrix-assisted laser desorption/ionization time-of-flight MS (MALDI-TOF MS). The peptide mass fingerprinting obtained was analyzed using Mascot (Matrix Science, London, UK) for protein identification.

The MS protocols and database search parameters were as follows: database, NCBInr; taxonomy, all entries/Viridiplantae (green plants); enzyme, trypsin; fixed modifications, carbamidomethyl (C); variable modifications, oxidation (M) and Gln->pyro-Glu (N-term Q); mass values, monoisotopic; protein mass, unrestricted; peptide mass tolerance, \pm 100 ppm; peptide charge state, $1^{+}$; max missed cleavages: 1 ; report top, 20-50; and data file, peaklist. Identification was considered positive if the protein was obtained with at least two independent peptides with an expectation value of $P<0.05$.

\section{Results}

2-DE. Triplicate gels were analyzed for each sample, which demonstrated a high level of reproducibility. Representative gels shown in Figure 1 indicate the differentially expressed protein spots in response to cold stress. More than 400 spots were reproducibly detected from digital image analysis on cCBB-stained gels over an isoelectric point range from 4 to 7 and molecular mass range from 10 to $100 \mathrm{kDa}$ (Fig. 1). Quantitative image analysis showed that only 41 protein spots had a significant change in intensity of at least 2 -fold relative to the control. Of these, 26 protein spots were up-regulated and 15 protein spots were down-regulated after the cold treatment.

IDENTIFICATION OF DIFFERENTIALLY-EXPRESSED PROTEINS. Of the 30 protein spots resolved on the gel, 28 protein spots were successfully identified through a Mascot database search. Two of the spots did not match any protein in the database, which may represent novel cold-responsive proteins. Of the 28 proteins, 22 protein spots were up-regulated and six protein spots were down-regulated after cold stress treatment (Fig. 1; Table 1). All protein sequences detected and identified were also searched against a gene ontology tool (www.geneontology. org). These identified proteins were found to be involved in diverse biological processes, including antioxidation and antipathogen, photosynthesis, molecular chaperones, protein synthesis, signal transduction, energy metabolism, and others (Fig. 2 ). The largest functional category possessed proteins involved in the antioxidation and antipathogen (28\%), including antioxidant responses, copper/zinc superoxide dismutase (SOD), ascorbate peroxidase (APX), ferredoxin-NADP reductase (FNR), and anthocyanidin synthase (ANS) as well as bio-stress responses, pathogenesis-related (PR) protein10.5, nucleotidebinding site leucine-rich repeat (NBS-LRR) protein, and 60 $\mathrm{kDa}$ jasmonate-induced protein (JIP60)-like isoform X2. The second largest category was photosynthesis (18\%). Among the proteins involved in photosynthesis, four protein spots were linked to the ribulose bisphosphate carboxylase/oxygenase ( $\mathrm{RuBisCo}$ ) and one protein spot was related to the chlorophyll binding protein. The next most prominent category was molecular chaperones (14\%). Proteins of this group included heat shock protein (HSP), heat stress transcription factor A-2 (HSFA2)-like, and protein-disulfide isomerase (PDI). The next category was energy metabolism (11\%), which included aconitate hydratase, phosphoglycerate mutase and short $\mathrm{Ca}^{2+}$-binding mitochondrial carrier (SCaMC). For the signal transduction (11\%) and protein synthesis (11\%) categories, proteins involved in ethylene signaling pathway and eukaryotic translation initiation and elongation factors were identified, respectively. The other functional categories (7\%) contained S-adenosylmethionine (SAM)-dependent methyltransferases and putative myosin heavy chain (Table 1).

\section{Discussion}

Cold stress has been regarded as a major stress for crops, especially tropic and subtropic crops, such as rubber (Hevea brasiliensis), cassava (Manihot esculenta), papaya (Carica papaya), and banana, and its negative effects have been studied extensively in many crops. At present, comparative proteomics analysis is often used to assess the complex cellular changes and characterization in plant responses to cold stress. In this study, proteome 
Table 1. Cold-responsive proteins identified in banana leaves by matrix-assisted laser desorption/ionization time-of-flight mass spectrometry (MALDI-TOF MS). ${ }^{z}$

\begin{tabular}{|c|c|c|c|c|c|c|c|c|c|c|c|}
\hline Spot $^{y}$ & Accession $^{\mathrm{x}}$ & Protein name & Organism & $\mathrm{EMr}^{\mathrm{w}}$ & EpI & $\mathrm{TMr}$ & TpI & Score & M & $\mathrm{C}$ & Exp \\
\hline \multicolumn{12}{|c|}{ Antioxidation and anti-pathogen } \\
\hline \multicolumn{12}{|c|}{ Antioxidation } \\
\hline 7 & AFV46365 & $\begin{array}{l}\text { Copper/zinc superoxide dismutase } \\
\text { CSD2A-1 (SOD) }\end{array}$ & Musa acuminata & 23.29 & 6.12 & 22.86 & 5.40 & 94 & 7 & 43 & Up \\
\hline 17 & AFV46369 & $\begin{array}{l}\text { Copper/zinc superoxide dismutase } \\
\text { (SOD) }\end{array}$ & M. acuminata & 22.05 & 7.19 & 23.11 & 6.11 & 57 & 5 & 21 & Down \\
\hline 27 & AAP42501 & Ascorbate peroxidase (APX) & Ipomoea batatas & 27.75 & 5.32 & 24.53 & 4.89 & 55 & 10 & 25 & Up \\
\hline 28 & AAB 82287 & Anthocyanidin synthase (ANS) & Matthiola incana & 40.79 & 5.54 & 30.50 & 5.04 & 57 & 7 & 27 & Up \\
\hline \multicolumn{12}{|c|}{ Anti-pathogen } \\
\hline 23 & EOY06623 & Pathogenesis-related protein 10.5 (PR) & Theobroma cacao & 17.55 & 5.14 & 38.36 & 5.10 & 73 & 9 & 54 & Up \\
\hline 25 & AFC90534 & $\begin{array}{l}\text { Nucleotide-binding site leucine-rich } \\
\text { repeat protein partial (NBS-LRR) }\end{array}$ & $\begin{array}{l}\text { Rhododendron } \\
\text { formosanum }\end{array}$ & 28.65 & 5.94 & 37.56 & 6.05 & 58 & 8 & 33 & Up \\
\hline 26 & XP_004982822 & $\begin{array}{l}60 \mathrm{kDa} \text { jasmonate-induced protein-like } \\
\text { isoform X2 (JIP60) }\end{array}$ & Setaria italica & 18.80 & 6.89 & 34.53 & 6.23 & 53 & 9 & 24 & Up \\
\hline 6 & AGB56405 & $\begin{array}{l}\text { Ribulose-1,5-bisphosphate carboxylase/ } \\
\text { oxygenase large subunit, chloroplast } \\
\text { (RuBisCo) }\end{array}$ & Renealmia cernua & 19.71 & 6.11 & 26.57 & 5.47 & 102 & 7 & 33 & Up \\
\hline 8 & Q7X999 & $\begin{array}{l}\text { Ribulose bisphosphate carboxylase/ } \\
\text { oxygenase (RuBisCo) activase } 2, \\
\text { chloroplastic }\end{array}$ & Larrea tridentata & 48.26 & 6.78 & 27.10 & 5.03 & 67 & 11 & 22 & Up \\
\hline 13 & AAM98163 & $\begin{array}{l}\text { Magnesium chelatase subunit of } \\
\text { protochlorophyllide reductase } \\
\text { (MCPR) }\end{array}$ & $\begin{array}{c}\text { Arabidopsis } \\
\text { thaliana }\end{array}$ & 46.50 & 5.36 & 47.57 & 5.90 & 65 & 15 & 38 & Up \\
\hline 19 & XP_002277357 & $\begin{array}{l}\text { RuBisCo large subunit-binding protein } \\
\text { subunit alpha, chloroplastic-like } \\
\text { (Rlsbp) }\end{array}$ & Vitis vinifera & 62.06 & 5.20 & 104.93 & 4.92 & 121 & 14 & 25 & Down \\
\hline \multicolumn{12}{|c|}{ Protein synthesis } \\
\hline 5 & AAQ08197 & $\begin{array}{l}\text { Eukaryotic translation initiation factor } \\
\text { 4A1 isoform, partial (eIF4A) }\end{array}$ & T. cacao & 37.78 & 5.55 & 24.29 & 5.94 & 68 & 7 & 26 & Up \\
\hline 9 & ACJ84967 & $\begin{array}{l}\text { Eukaryotic translation initiation factor } 3 \\
\text { subunit E-like (eIF3e) }\end{array}$ & $\begin{array}{l}\text { Medicago } \\
\text { truncatula }\end{array}$ & 24.57 & 4.81 & 22.29 & 5.75 & 76 & 8 & 33 & Down \\
\hline 21 & CAL53714 & $\begin{array}{l}\text { Protein translation elongation factor Ts } \\
\quad(\text { EF-Ts })\end{array}$ & O. tauri & 36.45 & 5.55 & 50.27 & 5.99 & 84 & 14 & 52 & Down \\
\hline \multicolumn{12}{|c|}{ Signal transduction } \\
\hline 10 & XP_004250139 & 14-3-3 protein 1-like & $\begin{array}{l}\text { Solanum } \\
\quad \text { lycopersicum }\end{array}$ & 28.36 & 4.76 & 23.56 & 4.47 & 56 & 7 & 32 & Up \\
\hline 22 & ADM64331 & $\begin{array}{l}\text { S-adenosyl-L-methionine (SAM) } \\
\text { synthase }\end{array}$ & M. acuminata & 43.69 & 5.72 & 55.81 & 6.14 & 113 & 13 & 38 & Up \\
\hline 24 & NP_001149427 & $\begin{array}{l}\text { 1-aminocyclopropane-1-carboxylate } \\
\text { oxidase } 1 \text { (ACO) }\end{array}$ & Zea mays & 34.76 & 4.99 & 34.50 & 4.74 & 52 & 6 & 18 & Down \\
\hline
\end{tabular}

Continued next page

expression of banana leaves was investigated in response to cold stress. Although we identified differentially expressed proteins that are involved in a number of cellular functions, including antioxidation and antipathogen, photosynthesis, chaperone, signal transduction, protein synthesis, energy metabolism, and other cellular functions, the largest changes occurred in proteins involved in antioxidation, pathogen defense, and energy supply in response to cold stress. Together, these data suggest that plant cells are able to monitor cold stress by modulating the expression of specific proteins. 
Table 1. Continued.

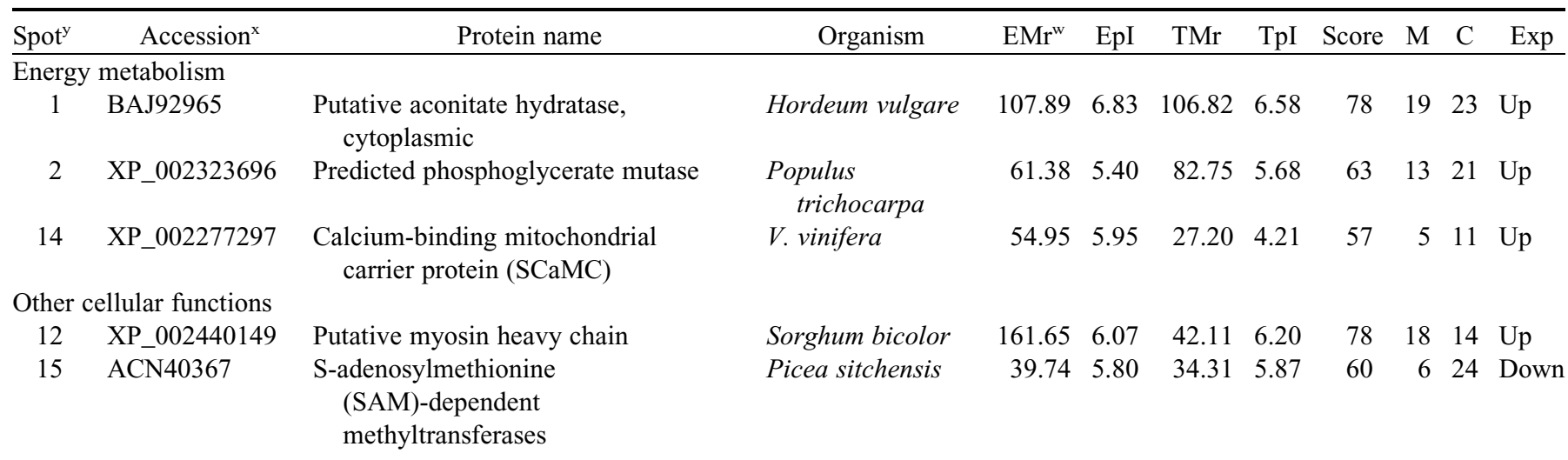

${ }^{\mathrm{z}}$ Banana plantlets were grown under growth chamber conditions $\left(5^{\circ} \mathrm{C}\right.$, relative humidity $70 \%, 12 \mathrm{~h}$ photoperiod and $100 \mu \mathrm{mol} \cdot \mathrm{m}^{-2} \cdot \mathrm{s}^{-1} \mathrm{PAR}$, the control sample treated for $0 \mathrm{~h}$ and the sample treated for $24 \mathrm{~h}$ ). Total protein was extracted and separated by two-dimensional gel electrophoresis. In isoelectric focusing, $400 \mu \mathrm{g}$ of protein was loaded onto immobilized $\mathrm{pH}$ gradient strips $(17 \mathrm{~cm}, \mathrm{pH} 4-7)$. Sodium dodecyl sulfate polyacrylamide gel electrophoresis was performed with $12 \%$ gels. The protein spots were stained with colloidal Coomassie brilliant blue G- 250 . Statistical and quantitative analyses were performed to compare the control and treated groups. For the statistic sets, the paired $t$ test was used at a significance level of $95 \%$. In the quantitative analysis, the upper and lower limits were set to 2.0 and 0.5 , respectively. The spots were compared among three biological replicates. Quantitative analysis revealed a total of 41 spots that had significant changes in intensity by at least 2-fold relative to the control. Of the 41 proteins, 30 proteins were digested with trypsin, and analyzed with MALDI-TOF MS. The peptide tags were submitted to sequence query with Mascot (Matrix Science, London, UK) for database search in NCBInr. 28 of the 30 proteins were known proteins and two proteins were novel proteins.

${ }^{y}$ Protein spot number corresponding to the 2-DE gels (Fig. 1).

${ }^{\mathrm{x}} \mathrm{NCBI}$ accession number.

${ }^{\mathrm{w}} \mathrm{EMr}=$ experimental molecular weight; $\mathrm{EpI}=$ experimental isoelectric point; $\mathrm{TMr}=$ theoretical molecular weight; $\mathrm{TpI}=$ theoretical isoelectric point; Score $=$ Mascot score for the most significant hits; $\mathrm{M}=$ number of mass values matched; $\mathrm{C}=$ percent sequence coverage; Exp $=$ expression .

\section{Proteins involved in antioxidation and antipathogen}

INCREASED ANTIOXIDATION. Cold stress has previously been shown to induce ROS accumulation in plant cells (Suzuki and Mittler, 2006). ROS are produced as byproducts of aerobic metabolism in plants (Apel and Hirt, 2004), and have a dual function as both damaging and signaling compounds (Mittler et al., 2004; Møller and Sweetlove, 2010). On one hand, stressinduced ROS are hazardous to oxidizing lipids, proteins, and nucleic acids, but on the other hand, they can also act as signals that activate defense pathways in response to biotic attack (Keunen et al., 2013), including the hypersensitive response to pathogens (Rhoads et al., 2006). Surprisingly, we found that cold stress induced an increase in the expression of SOD and APX in banana leaves, while the expression of another isoenzyme of SOD slightly decreased (Table 1). The simultaneous up- and down-regulation in different isoenzymes has been detected under cold stress conditions, similar to what has been described in zoysiagrass (Zoysia japonica) stolons exposed to cold stress, and Xuan et al. (2013) confirmed that functionally different APX proteins differentially respond to cold stress. Scavenging for increased ROS at low temperatures can be achieved by shifting protein expression to produce isoforms that have improved performance at low temperature. In addition, specific FNR and ANS genes were up-regulated in response to cold stress in banana leaves (Table 1). FNR is an important protein involved in plant photosynthesis and plays a role in quenching ROS (Lintala et al., 2012; Mulo, 2011). Moreover, the expression level of FNR genes has been shown to increase upon drought stress (Lehtimäki et al., 2010). The anthocyanins, which are water-soluble vacuolar pigments that may appear red, purple, or blue depending on the $\mathrm{pH}$, belonging to the flavonoid family, are found in plant tissues as diverse as leaves, flowers, fruit, and seeds (Lim et al., 2013), and have been reported to possess a variety of biomedicinal properties, including antioxidative, antimutagenic, antimicrobial, antiinflammatory, and antihypertensive activity (Cheng et al., 2007). ANS, which is an enzyme involved in anthocyanin biosynthesis, catalyzes the reaction from the colorless leucoanthocyanidins to the colored anthocyanidins (Nakajima et al., 2001). The abundant activities of functional proteins that work cooperatively can contribute to establishing a new cellular redox homeostasis under cold stress conditions in banana leaves.

INCREASED PATHOGEN RESISTANCE. Plants that survive through winter are simultaneously exposed to abio- and bio-stress. Therefore, it is not surprising that cold stress induced an increase in the abundance of defense-related proteins. To have protection from microbial pathogen infection, plants have evolved a large number of immune receptors, such as PR proteins, resistance proteins, and disease resistance proteins, which sense pathogenderived molecules and trigger a defense response (Jones and Dangl, 2006). Treatment with cold significantly increased the abundance of three defense-related proteins (a PR protein 10.5, a NBS-LRR protein, and a JIP60-like isoform X2) in this study (Table 1). PR proteins have been defined as defense-related proteins in plants that are encoded by the host plant but induced by pathogens and stress (Agarwal and Agarwal, 2014). The abundance of PR proteins in moss was found to increase in response to cold stress (Wang et al., 2009). NBS-LRR proteins make up the majority of disease resistance proteins in plants (Yue et al., 2012). In addition, ribosome-inactivating proteins (RIPs) belong to a large family of ubiquitous proteins with antiviral and antifungal properties (Van Damme et al., 2001). JIP60 is a RIP (Chaudhry et al., 1994) involved in the plant stress response (Reinbothe et al., 1994). Therefore, cold stress can lead to an increase in the expression of disease resistance proteins in plants (Dumont et al., 2011). 


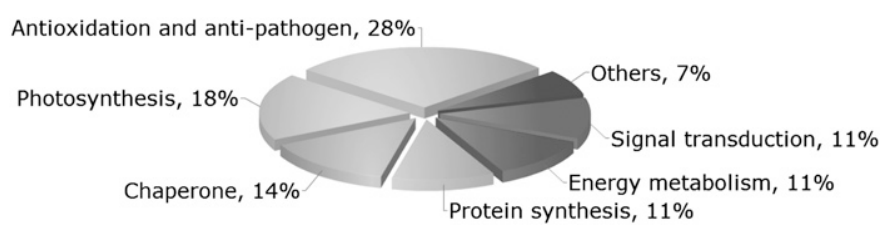

Fig. 2. Distribution of the functional categories of the proteins identified as having differential expression patterns after cold exposure compared with control banana leaves. Total protein was extracted and separated by twodimensional gel electrophoresis. In isoelectric focusing, $400 \mu \mathrm{g}$ of protein was loaded onto immobilized $\mathrm{pH}$ gradient strips $(17 \mathrm{~cm}, \mathrm{pH} 4-7)$. Sodium dodecyl sulfate polyacrylamide gel electrophoresis was performed with $12 \%$ gels. The protein spots were stained with colloidal Coomassie brilliant blue G-250. Statistical and quantitative analyses were performed to compare the control and treated groups. For the statistic sets, the paired $t$ test was used at a significance level of $95 \%$. In the quantitative analysis, the upper and lower limits were set to 2.0 and 0.5 , respectively. The spots were compared among three biological replicates. Quantitative analysis revealed a total of 41 spots that had significant changes in intensity by at least 2-fold relative to the control. Of the 41 proteins, 30 proteins were digested with trypsin, and analyzed with matrix-assisted laser desorption/ionization time-of-flight mass spectrometry. The peptide tags were submitted to sequence query with Mascot for database search in NCBInr. 28 of the 30 proteins were known proteins and two proteins were novel proteins. The known proteins that showed a statistically significant change were functionally sorted into seven functional categories according to the Gene Ontology annotation.

\section{Involvement in photosynthesis}

Plant photosynthesis is inhibited at low temperature, because the capacity of many photosynthetic enzymes, such as RuBisCo, is affected by cold stress (Yamori et al., 2014). RuBisCo is the key regulatory enzyme responsible for $\mathrm{CO}_{2}$ fixation during photosynthesis. It is localized in the chloroplast stroma and is composed of eight small subunits encoded by a small nuclear multigene family as well as eight large subunits encoded by a single gene in the multicopy chloroplast genome (Basha et al., 2009). RuBisCo activase maintains maximal photosynthetic rates by using the energy from adenosine triphosphate (ATP) hydrolysis to release tight binding inhibitors from the active site of RuBisCo (Keown et al., 2013). It also has another role as a chaperone during stress (Sobhanian et al., 2010). RuBisCo large subunit-binding protein (Rlsbp) subunit alpha is implicated in the assembly of the RuBisCo oligomer (Roy and Cannon, 1988). Magnesium chelatase subunit of protochlorophyllide reductase (MCPR) catalyzes light-dependent reduction of the divinyl- and monovinyl-derivatives of the nonesterified chlorophyll precursor protochlorophyllide in the biosynthesis of chlorophylls (Frick et al., 2003). RuBisCo activase and MCPR were found to be up-regulated in banana leaves under cold stress in this study, but the alpha subunit of Rlsbp was decreased (Table 1). Cold treatment can increase the abundance of RuBisCo and RuBisCo activase (Dumont et al., 2011; Wang et al., 2009; Xuan et al., 2013). When photosynthesis is greatly inhibited by low temperature in various crops (Allen and Ort, 2001; Jin et al., 2011), they can increase the levels of RuBisCo, RuBisCo activase, and MCPR, which are needed to compensate for decreased activities of the enzymes at low temperatures (Yamori et al., 2014). Although the alpha subunit of Rlsbp may inhibit RuBisCo activities under cold stress conditions, the reason for the decreased levels after exposure to cold stress will require further clarification.

\section{Involvement with molecular chaperones}

Molecular chaperones are involved in the assistance of protein folding together with the prevention and recovery of polypeptide aggregation, which may occur during protein biosynthesis and during stress situations (Hinault and Goloubinoff, 2007). As molecular chaperones, Hsps are required to protect plant cells from cold damage (Wang et al., 2009) and can help other proteins maintain or regain their native conformation by stabilizing partially unfolded states (Boston et al., 1996). In response to heat stress, HSFA2 can act as a transcription activator of genes involved in metabolism and redox homeostasis (Liu and Charng, 2013). In addition, HSFA 2 also regulates a large number of chaperones and co-chaperones, as well as genes involved in multiple phytohormone signaling pathways (Liu and Charng, 2013). PDIs also play a role as chaperones in the quality control system for correct protein folding (Onda et al., 2011). In this study, two Hsps and one HSFA2 were up-regulated by cold stress, and therefore may play important roles similar to that under heat stress conditions. In addition, one PDI gene was induced by cold stress in this study (Table 1). The up-regulation of molecular chaperones is important for the folding, assembly, and stabilization of membranes and proteins. This mechanism also guarantees the quality of proteins that are essential for plant tolerance to cold stress conditions.

\section{Involvement in protein synthesis}

Eukaryotic translation initiation factor 4A (eIF4A), ATPdependent ribonucleic acid (RNA) helicase, and the binding of eIF4A together with eIF4B promotes unwinding of mRNA secondary structure (Aitken and Lorsch, 2012). It has been shown that eIF4A silencing inhibits plant growth, but tobacco mosaic virus (TMV) accumulation did not decrease in these plants (Hwang et al., 2013). Eukaryotic translation initiation factor $3 \mathrm{E}$ (eIF3e) has been implicated in the regulation of translation (Paz-Aviram et al., 2008). Translation elongation factors Ts (EF-Ts) is an important component of the protein translation system, whereby it has inhibitory effects on the guanosine triphosphatase activity of elongation factor $\mathrm{Tu}$ and enhances guanosine diphosphate release (Palmer et al., 2013). In this study, we found that the expression of proteins involved in protein synthesis, such as eIF3e and EF-Ts, was repressed under cold stress conditions, but eIF4A expression was induced (Table 1). One hypothesis is that eIF3e and EF-Ts preset in the host may be commandeered to synthesize pathogenic proteins, but eIF4A is not used by pathogens under cold stress conditions, so the host only represses the expression of eIF3e and EF-Ts in response to cold stress. The increased accumulation of eIF4A suggests that under cold stress conditions, plants may synthesize important proteins involved in cold resistance or acclimation.

\section{Involvement in signal transduction}

Ethylene is a gaseous plant hormone that regulates essentially all plant growth and developmental processes, including germination, leaf and flower senescence and abscission, nodulation, fruit ripening, and the response to a wide variety of stresses (Yoon and Kieber, 2013). SAM is a precursor for the biosynthesis of ethylene and polyamines (PAs) and is synthesized by SAM synthetase (Cui et al., 2005). The 1-aminocyclopropane-1-carboxylic acid (ACC) is converted into ethylene by ACC oxidase (ACO), which is the final step of ethylene biosynthesis (Yang and Hoffman, 1984). In this study, SAM was up-regulated, while ACO was downregulated by cold stress (Table 1), which suggests that biosynthesis of ethylene may be inhibited leading to the accumulation of PAs in response to cold stress. PAs can control the levels of abscisic acid (ABA) in response to cold by modulating ABA biosynthesis at the transcriptional level (Cuevas 
et al., 2009). In addition, PAs play important roles in the tolerance of plants against cold stress, which contributes to the enhancement of ROS scavenging systems (Abavisani et al., 2013; Çakmak and Atici, 2009; Zhang et al., 2009). The 14-3-3 proteins are phosphoserine-binding proteins that modulate the functions of a diverse range of proteins via direct proteinprotein interactions, such as with kinases, transcription factors, structural proteins, ion channels, and pathogen defense-related proteins (Abreu et al., 2013; Denison et al., 2011). In addition, 14-3-3 proteins appear to be involved in the brassinosteroids, ABA, and giberellic acid signaling pathways during stress response (Denison et al., 2011). One 14-3-3 protein was induced by cold stress in our study (Table 1), and numerous proteomic studies have shown a differential accumulation of 143-3 proteins in response to cold stress in plants (Chattopadhyay et al., 2011; Hashimoto and Komatsu, 2007; Wang et al., 2012; $\mathrm{Xu}$ et al., 2012).

\section{Involvement in energy metabolism}

Alteration of energy metabolism under cold stress conditions can be affected by enzymes involved in glycolysis (Yan et al., 2006) and the tricarboxylic acid (TCA) cycle (Li et al., 2011). SCaMC mediates ATP-Mg/Pi exchange and plays important roles in energy metabolism (Yang et al., 2014). Aconitate hydratase is involved in the TCA cycle and was found to be up-regulated under cold stress conditions, and a similar trend was observed for phosphoglycerate mutase, which is involved in glycolysis, and SCaMC, which is involved in energy metabolism (Table 1). Thus, enhanced levels of these primary metabolismrelated enzymes indicate that adequate energy is a prerequisite for how plants deal with cold stress conditions.

\section{Involvement in other cellular functions}

In this study, SAM-dependent methyltransferases were downregulated and putative myosin heavy chain was up-regulated by cold stress conditions (Table 1). Methylation of proteins, nucleotides, and sugars is crucial for metabolism, cell signaling, and epigenetic programming, and a methyl group is most often added by SAM-dependent methyltransferases (Grove et al., 2011). The plant myosins use the energy from ATP hydrolysis to drive transportation of various intracellular cargos, including membranous organelles, protein complexes, mRNAs, along tracks of cytoskeletal polymers (Wang et al., 2014).

Yang et al. (2012) hypothesized that greater cold resistance found in plantain may be associated with increased ROS scavenging capability, reduced ROS production, and decreased lipid peroxidation. Surprisingly, our results showed that increased antioxidation capability to scavenge ROS and reduce ROS production also exists in response to cold stress conditions in banana. Therefore, we postulate that increased antioxidation ability could be a common characteristic of banana and plantain in response to cold stress conditions. In addition, an increased defense capability and energy supply were also found to occur in response to cold stress conditions in banana.

\section{Conclusions}

In conclusion, 28 differentially-expressed proteins were identified in response to cold stress conditions in banana that are involved in several cellular processes, including antioxidation and antipathogen, photosynthesis, chaperones, protein synthesis, signal transduction, energy metabolism, and other cellular functions. Proteins related to antioxidation, pathogen resistance, molecular chaperones, and energy metabolism were increased, while proteins related to ethylene synthesis, protein synthesis, and epigenetic modification were decreased in response to cold temperature treatment. The banana plantlets incubated at cold temperatures demonstrated major changes in increased ROS scavenging, defense against diseases, and energy supply. Based on these findings, ROS, pathogens, and energy deficiency would be predominantly deleterious to banana plants under cold stress conditions. Increased antioxidation capability in banana was also discovered in plantain, which has greater cold tolerance than banana in response to cold stress conditions. Therefore, we hypothesized that an increased antioxidation ability could be a common characteristic of banana and plantain in response to cold stress conditions. Changes in the expression levels of these proteins contribute to our understanding of the physiological processes of banana in response to cold stress conditions. Importantly, some of the identified cold stress response-related proteins may be useful biomarkers to facilitate conventional breeding approaches for cold-tolerant banana cultivars.

\section{Literature Cited}

Abavisani, A., M. Khorshidi, and A. Sherafatmandjour. 2013. Interaction between cold stress and polyamine on antioxidant properties in dragonhead. Intl. J. Agr. Crop Sci. 5:2555-2560.

Abdalla, K.O. and M.S. Rafudeen. 2012. Analysis of the nuclear proteome of the resurrection plant Xerophyta viscosa in response to dehydration stress using iTRAQ with 2DLC and tandem mass spectrometry. J. Proteomics 75:2361-2374.

Abreu, I.A., A.P. Farinha, S. Negrão, N. Gonçalves, C. Fonseca, M. Rodrigues, R. Batista, N.J. Saibo, and M.M. Oliveira. 2013. Coping with abiotic stress: Proteome changes for crop improvement. J. Proteomics 93:145-168.

Agarwal, P. and P.K. Agarwal. 2014. Pathogenesis related-10 proteins are small, structurally similar but with diverse role in stress signaling. Mol. Biol. Rpt. 41:599-611.

Aitken, C.E. and J.R. Lorsch. 2012. A mechanistic overview of translation initiation in eukaryotes. Nat. Struct. Mol. Biol. 19:568-576.

Allen, D.J. and D.R. Ort. 2001. Impacts of chilling temperatures on photosynthesis in warm-climate plants. Trends Plant Sci. 6:36-42.

Apel, K. and H. Hirt. 2004. Reactive oxygen species: Metabolism, oxidative stress, and signal transduction. Annu. Rev. Plant Biol. 55:373-399.

Barrero-Gil, J. and J. Salinas. 2013. Post-translational regulation of cold acclimation response. Plant Sci. 205-206:48-54.

Basha, S., R. Katam, H. Vasanthaiah, and F.B. Matta. 2009. Proteome analysis of muscadine grape leaves. Intl. J. Wine Res. 1:161-173.

Boston, R.S., P.V. Viitanen, and E. Vierling. 1996. Molecular chaperones and protein folding in plants. Plant Mol. Biol. 32:191-222.

Bradford, M.M. 1976. A rapid and sensitive method for the quantification of microgram quantities of protein utilizing the principle of protein-dye binding. Anal. Biochem. 72:248-254.

Çakmak, T. and Ö. Atici. 2009. Effects of putrescine and low temperature on the apoplastic antioxidant enzymes in the leaves of two wheat cultivars. Plant Soil Environ. 55:320-326.

Carpentier, S.C., E. Witters, K. Laukens, H. Van Onckelen, R. Swennen, and B. Panis. 2007. Banana (Musa spp.) as a model to study the meristem proteome: Acclimation to osmotic stress. Proteomics 7:92105.

Chattopadhyay, A., P. Subba, A. Pandey, D. Bhushan, R. Kumar, A. Datta, S. Chakraborty, and N. Chakraborty. 2011. Analysis of the grasspea proteome and identification of stress-responsive proteins upon exposure to high salinity, low temperature, and abscisic acid treatment. Phytochemistry 72:1293-1307. 
Chaudhry, B., F. Müller-Uri, V. Cameron-Mills, S. Gough, D. Simpson, K. Skriver, and J. Mundy. 1994. The barley $60 \mathrm{kDa}$ jasmonate-induced protein (JIP60) is a novel ribosome-inactivating protein. Plant J. 6:815-824.

Cheng, L., Y. Xu, E. Grotewold, Z. Jin, F. Wu, C. Fu, and D. Zhao. 2007. Characterization of anthocyanidin synthase (ANS) gene and anthocyanidin in rare medicinal plant Saussurea medusa. Plant Cell Tissue Organ Cult. 89:63-73.

Chinnusamy, V., J. Zhu, and J.K. Zhu. 2007. Cold stress regulation of gene expression in plants. Trends Plant Sci. 12:444-451.

Cuevas, J.C., R. Lopez-Cobollo, R. Alcazar, X. Zarza, C. Koncz, T. Altabella, J. Salinas, A.F. Tiburcio, and A. Ferrando. 2009. Putrescine as a signal to modulate the indispensable ABA increase under cold stress. Plant Signal. Behav. 4:219-220.

Cui, S., F. Huang, J. Wang, X. Ma, Y. Cheng, and J. Liu. 2005. A proteomic analysis of cold stress responses in rice seedlings. Proteomics 5:3162-3172.

Davey, M.W., R. Gudimella, J.A. Harikrishna, L.W. Sin, N. Khalid, and J. Keulemans. 2013. A draft Musa balbisiana genome sequence for molecular genetics in polyploid, inter- and intra-specific Musa hybrids. BMC Genomics doi: 10.1186/1471-2164-14-683.

Denison, F.C., A.L. Paul, A.K. Zupanska, and R.J. Ferl. 2011. 14-3-3 proteins in plant physiology. Semin. Cell Dev. Biol. 22:720-727.

D’Hont, A., F. Denoeud, J.M. Aury, F.C. Baurens, F. Carreel, O. Garsmeur, B. Noel, S. Bocs, G. Droc, M. Rouard, C. Da Silva, K. Jabbari, C. Cardi, J. Poulain, M. Souquet, K. Labadie, C. Jourda, J. Lengellé, M. RodierGoud, A. Alberti, M. Bernard, M. Correa, S. Ayyampalayam, M.R. Mckain, J. Leebens-Mack, D. Burgess, M. Freeling, D. Mbéguié-AMbéguié, M. Chabannes, T. Wicker, O. Panaud, J. Barbosa, E. Hribova, P. Heslop-Harrison, R. Habas, R. Rivallan, P. Francois, C. Poiron, A. Kilian, D. Burthia, C. Jenny, F. Bakry, S. Brown, V. Guignon, G. Kema, M. Dita, C. Waalwijk, S. Joseph, A. Dievart, O. Jaillon, J. Leclercq, X. Argout, E. Lyons, A. Almeida, M. Jeridi, J. Dolezel, N. Roux, A.M. Risterucci, J. Weissenbach, M. Ruiz, J.C. Glaszmann, F. Quétier, N. Yahiaoui, and P. Wincker. 2012. The banana (Musa acuminata) genome and the evolution of monocotyledonous plants. Nature 488:213-217.

Dumont, E., N. Bahrman, E. Goulas, B. Valot, H. Sellier, J.L. Hilbert, C. Vuylsteker, I. Lejeune-Hénaut, and B. Delbreil. 2011. A proteomic approach to decipher chilling response from cold acclimation in pea (Pisum sativum L.). Plant Sci. 180:86-98.

Esteve, C., A. D'Amato, M.L. Marina, M.C. García, and P.G. Righetti. 2013. In-depth proteomic analysis of banana (Musa spp.) fruit with combinatorial peptide ligand libraries. Electrophoresis 34:207-214.

Feng, R.J., L.F. Lu, K.H. Yuan, P. Cheng, L.L. Zhang, J.F. Qi, Y. Ren, X.L. Xu, X.B. Zhang, L.Y. Zhou, and Y.D. Zhang. 2010. Cloning and expression analysis of rubredoxin from cold-treated banana leaves. Phyton-Intl. J. Expt. Bot. 79:163-168.

Frick, G., Q. Su, K. Apel, and G.A. Armstrong. 2003. An Arabidopsis porB porC double mutant lacking light-dependent NADPH:protochlorophyllide oxidoreductases $\mathrm{B}$ and $\mathrm{C}$ is highly chlorophylldeficient and developmentally arrested. Plant J. 35:141-153.

Gao, L., X. Yan, X. Li, G. Guo, Y. Hu, W. Ma, and Y. Yan. 2011. Proteome analysis of wheat leaf under salt stress by two-dimensional difference gel electrophoresis (2D-DIGE). Phytochemistry 72:1180 1191.

Ghosh, D. and J. Xu. 2014. Abiotic stress responses in plant roots: A proteomics perspective. Front. Plant Sci. doi: 10.3389/ fpls.2014.00006.

Grove, T.L., J.S. Benner, M.I. Radle, J.H. Ahlum, B.J. Landgraf, C. Krebs, and S.J. Booker. 2011. A radically different mechanism for $\mathrm{S}$-adenosylmethionine-dependent methyltransferases. Science 332:604-607.

Hashimoto, M. and S. Komatsu. 2007. Proteomic analysis of rice seedlings during cold stress. Proteomics 7:1293-1302.

Heslop-Harrison, J.S. and T. Schwarzacher. 2007. Domestication, genomics and the future for banana. Ann. Bot. (Lond.) 100:1073-1084.

Hinault, M.P. and P. Goloubinoff. 2007. Molecular crime and cellular punishment: Active detoxification of misfolded and aggregated proteins in the cell by the chaperone and protease networks. Adv. Exp. Med. Biol. 594:47-54.

Hwang, J., C.S. Oh, and B.C. Kang. 2013. Translation elongation factor 1B (eEF1B) is an essential host factor for Tobacco mosaic virus infection in plants. Virology 439:105-114.

Jin, Y., C. Zhang, H. Yang, Y. Yang, C. Huang, Y. Tian, and X. Lu. 2011. Proteomic analysis of cold stress responses in tobacco seedlings. Afr. J. Biotechnol. 10:18991-19004.

Jones, J.D.G. and J.L. Dangl. 2006. The plant immune system. Nature 444:323-329.

Keown, J.R., M.D. Griffin, H.D. Mertens, and F.G. Pearce. 2013. Small oligomers of ribulose-bisphosphate carboxylase/oxygenase (RuBisCo) activase are required for biological activity. J. Biol. Chem. 288:20607-20615.

Keunen, E., D. Peshev, J. Vangronsveld, W. van den Ende, and A. Cuypers. 2013. Plant sugars are crucial players in the oxidative challenge during abiotic stress: Extending the traditional concept. Plant Cell Environ. 36:1242-1255.

Lehtimäki, N., M. Lintala, Y. Allahverdiyeva, E.M. Aro, and P. Mulo. 2010. Drought stress-induced upregulation of components involved in ferredoxin-dependent cyclic electron transfer. J. Plant Physiol. 167:1018-1022.

Lescot, M., P. Piffanelli, A.Y. Ciampi, M. Ruiz, G. Blanc, J. LeebensMack, F.R. da Silva, C.M. Santos, A. D'Hont, O. Garsmeur, A.D. Vilarinhos, H. Kanamori, T. Matsumoto, C.M. Ronning, F. Cheung, B.J. Haas, R. Althoff, T. Arbogast, E. Hine, G.J. Pappas, T. Sasaki, M.T. Souza, R.N. Miller, J.C. Glaszmann, and C.D. Town. 2008. Insights into the Musa genome: Syntenic relationships to rice and between Musa species. BMC Genomics doi: 10.1186/1471-2164-9-58. Li, T., S.L. Xu, J.A. Oses-Prieto, S. Putil, P. Xu, R.J. Wang, K.H. Li, D.A. Maltby, L.H. An, A.L. Burlingame, Z.P. Deng, and Z.Y. Wang. 2011. Proteomics analysis reveals post-translational mechanisms for coldinduced metabolic changes in Arabidopsis. Mol. Plant 4:361-374.

Lim, S.H., J.K. Kim, J.Y. Lee, Y.M. Kim, S.H. Sohn, D.H. Kim, and S.H. Ha. 2013. Petal-specific activity of the promoter of the anthocyanidin synthase gene of tobacco (Nicotiana tabacum L.). Plant Cell Tissue Organ Cult. 114:373-383.

Lintala, M., N. Lehtimäki, J.P. Benz, A. Jungfer, J. Soll, E.M. Aro, B. Bölter, and P. Mulo. 2012. Depletion of leaf-type ferredoxin$\mathrm{NADP}^{+}$oxidoreductase results in the permanent induction of photoprotective mechanisms in Arabidopsis chloroplasts. Plant J. 70:809-817.

Liu, H.C. and Y.Y. Charng. 2013. Common and distinct functions of Arabidopsis class A1 and A2 heat shock factors indiverse abiotic stress responses and development. Plant Physiol. 163:276-290.

Mittler, R., S. Vanderauwera, M. Gollery, and F. Van Breusegem. 2004. Reactive oxygen gene network of plants. Trends Plant Sci. 9:490-498.

Miura, K. and T. Furumoto. 2013. Cold signaling and cold response in plants. Intl. J. Mol. Sci. 14:5312-5337.

Møller, I.M. and L.J. Sweetlove. 2010. ROS signalling - Specificity is required. Trends Plant Sci. 15:370-374.

Mulo, P. 2011. Chloroplast-targeted ferredoxin-NADP ${ }^{+}$oxidoreductase (FNR): Structure, function and location. Biochim. Biophys. Acta 1807:927-934.

Nakajima, J., Y. Tanaka, M. Yamazaki, and K. Saito. 2001. Reaction mechanism from leucoanthocyanidin to anthocyanidin 3-glucoside, a key reaction for coloring in anthocyanin biosynthesis. J. Biol. Chem. 276:25797-25803.

Onda, Y., A. Nagamine, M. Sakurai, T. Kumamaru, M. Ogawa, and Y. Kawagoe. 2011. Distinct roles of protein disulfide isomerase and P5 sulfhydryl oxidoreductases in multiple pathways for oxidation of structurally diverse storage proteins in rice. Plant Cell 23:210223.

Palmer, S.O., E.Y. Rangel, A.E. Montalvo, A.T. Tran, K.C. Ferguson, and J.M. Bullard. 2013. Cloning and characterization of EF-Tu and EF-Ts from Pseudomonas aeruginosa. BioMed Res. Intl. doi: 10.1155/ 2013/585748. 
Paz-Aviram, T., A. Yahalom, and D.A. Chamovitz. 2008. Arabidopsis eIF3e interacts with subunits of the ribosome, Cop9 signalosome and proteasome. Plant Signal. Behav. 3:409-411.

Reinbothe, S., C. Reinbothe, J. Lehmann, W. Becker, K. Apel, and B. Parthier. 1994. JIP60, a methyl jasmonate-induced ribosomeinactivating protein involved in plant stress reactions. Proc. Natl. Acad. Sci. USA 91:7012-7016.

Rhoads, D.M., A.L. Umbach, C.C. Subbaiah, and J.N. Siedow. 2006. Mitochondrial reactive oxygen species. Contribution to oxidative stress and interorganellar signaling. Plant Physiol. 141:357-366.

Roy, H. and S. Cannon. 1988. Ribulose bisphosphate carboxylase assembly: What is the role of the large subunit binding protein? Trends Biochem. Sci. 13:163-165.

Samyn, B., K. Sergeant, S. Carpentier, G. Debyser, B. Panis, R. Swennen, and J. Van Beeumen. 2007. Functional proteome analysis of the banana plant (Musa spp.) using de novo sequence analysis of derivatized peptides. J. Proteome Res. 6:70-80.

Sanghera, G.S., S.H. Wani, W. Hussain, and N.B. Singh. 2011. Engineering cold stress tolerance in crop plants. Curr. Genomics $12: 30-43$.

Sobhanian, H., R. Razavizadeh, Y. Nanjo, A.A. Ehsanpour, F.R. Jazii, N. Motamed, and S. Komatsu. 2010. Proteome analysis of soybean leaves, hypocotyls and roots under salt stress. Proteome Sci. doi: 10.1186/ 1477-5956-8-19.

Suzuki, N. and R. Mittler. 2006. Reactive oxygen species and temperature stresses: A delicate balance between signaling and destruction. Physiol. Plant. 126:45-51.

Thomashow, M.F. 1999. Plant cold acclimation: Freezing tolerance genes and regulatory mechanisms. Annu. Rev. Plant Physiol. Plant Mol. Biol. 50:571-599.

Toledo, T.T., S.B. Nogueira, B.R. Cordenunsi, F.C. Gozzo, E.J. Pilau, F.M. Lajolo, and J.R.O. do Nascimento. 2012. Proteomic analysis of banana fruit reveals proteins that are differentially accumulated during ripening. Postharvest Biol. Technol. 70:51-58.

Van Damme, E.J.M., Q. Hao, Y. Chen, A. Barre, F. Vandenbussche, S. Desmyter, P. Rougé, and W.J. Peumans. 2001. Ribosomeinactivating proteins: A family of plant proteins that do more than inactivate ribosomes. Crit. Rev. Plant Sci. 20:395-465.

Vanhove, A.C., W. Vermaelen, B. Panis, R. Swennen, and S.C. Carpentier. 2012. Screening the banana biodiversity for drought tolerance: Can an in vitro growth model and proteomics be used as a tool to discover tolerant varieties and understand homeostasis. Front. Plant Sci. doi: 10.3389/fpls.2012.00176.

Wang, G., M. Zhong, J. Wang, J. Zhang, Y. Tang, G. Wang, and R. Song. 2014. Genome-wide identification, splicing, and expression analysis of the myosin gene family in maize (Zea mays). J. Expt. Bot. 65:923-938.

Wang, X., Y. Liu, and P. Yang. 2012. Proteomic studies of the abiotic stresses response in model moss - Physcomitrella patens. Front. Plant Sci. doi: $10.3389 /$ fpls.2012.00258.
Wang, X., P. Yang, X. Zhang, Y. Xu, T. Kuang, S. Shen, and Y. He. 2009. Proteomic analysis of the cold stress response in the moss, Physcomitrella patens. Proteomics 9:4529-4538.

Xu, W., W. Shi, L. Jia, J. Liang, and J. Zhang. 2012. TFT6 and TFT7, two different members of tomato 14-3-3 gene family, play distinct roles in plant adaption to low phosphorus stress. Plant Cell Environ. 35:1393-1406.

Xuan, J., Y. Song, H. Zhang, J. Liu, Z. Guo, and Y. Hua. 2013. Comparative proteomic analysis of the stolon cold stress response between the $\mathrm{C}_{4}$ perennial grass species Zoysia japonica and Zoysia metrella. PLoS One doi: 10.1371/journal.pone.0075705.

Yamori, W., K. Hikosaka, and D.A. Way. 2014. Temperature response of photosynthesis in $\mathrm{C} 3, \mathrm{C} 4$, and CAM plants: Temperature acclimation and temperature adaptation. Photosynth. Res. 119:101-117.

Yan, S.P., Q.Y. Zhang, Z.C. Tang, W.A. Su, and W.N. Sunday. 2006. Comparative proteomic analysis provides new insights into chilling stress responses in rice. Mol. Cell. Proteomics 5:484-496.

Yang, Q., S. Brüschweiler, and J.J. Chou. 2014. A self-sequestered calmodulin-like $\mathrm{Ca}^{2+}$ sensor of mitochondrial SCaMC carrier and its implication to $\mathrm{Ca}^{2+}$-dependent ATP-Mg/P(i) transport. Structure 22:209-217.

Yang, Q.S., J.H. Wu, C.Y. Li, Y.R. Wei, O. Sheng, C.H. Hu, R.B. Kuang, Y.H. Huang, X.X. Peng, J.A. McCardle, W. Chen, Y. Yang, J.K. Rose, S. Zhang, and G.J. Yi. 2012. Quantitative proteomic analysis reveals that antioxidation mechanisms contribute to cold tolerance in plantain (Musa paradisiaca L.; ABB Group) seedlings. Mol. Cell. Proteomics 11:1853-1869.

Yang, S.F. and N.E. Hoffman. 1984. Ethylene biosynthesis and its regulation in higher plants. Annu. Rev. Plant Physiol. 35:155189.

Yoon, G.M. and J.J. Kieber. 2013. 1-Aminocyclopropane-1-carboxylic acid as a signalling molecule in plants. AoB Plants doi:10.1093/aobpla/ plt017.

Yue, J.X., B.C. Meyers, J.Q. Chen, D. Tian, and S. Yang. 2012. Tracing the origin and evolutionary history of plant nucleotidebinding site-leucine-rich repeat (NBS-LRR) genes. New Phytol. 193:1049-1063.

Zhang, L.L., R.J. Feng, and Y.D. Zhang. 2012. Evaluation of different methods of protein extraction and identification of differentially expressed proteins upon ethylene-induced early-ripening in banana peels. J. Sci. Food Agr. 92:2106-2115.

Zhang, M., G. Li, W. Huang, T. Bi, G. Chen, Z. Tang, W. Su, and W. Sunday. 2010. Proteomic study of Carissa spinarumin response to combined heat and drought stress. Proteomics 10:3117-3129.

Zhang, W., B. Jiang, W. Li, H. Song, Y. Yu, and J. Chen. 2009. Polyamines enhance chilling tolerance of cucumber (Cucumis sativus L.) through modulating antioxidative system. Sci. Hort. 122:200-208. 